\title{
Serious games in virtual environments for health teaching and learning
}

\author{
Jogos sérios em ambiente virtual para ensino-aprendizagem na saúde
}

Cristiano Alves dos Santos ${ }^{1}$, Valtuir Duarte Souza-Junior ${ }^{1}$, Flávio Ferreira Lanza², Allan Jonny Lacerda², Beatriz Maria Jorge ${ }^{1}$, Isabel Amélia Costa Mendes ${ }^{1}$

Objective: to identify the evolution in the use of serious games in virtual environments for health teaching and learning in the literature. Methods: integrative review with searches in the databases: Web of Science, National Library of Medicine, Cumulative Index to Nursing and Allied Health Literature. Results: in total, 82,779 articles were identified, 13 of which were fully read. Serious games are cheaper than simulated surgical procedures, easy to access and appropriate for the development of surgical skills and the training of patients, skills, clinical reasoning and decision taking. Conclusion: serious games have been developed through the elaboration of software and specific interactivity tools, mainly focused on skills development; using internet components, especially in Medicine and Nursing; and use peripherals of the computers in the teaching-learning strategies to encourage clinical reasoning and decision making.

Descriptors: Video Games; Simulation Training; Health Education; Software Validation.

Objetivo: identificar na literatura como tem evoluído o uso de jogos sérios em ambiente virtual para o ensinoaprendizagem na saúde. Métodos: revisão integrativa, com buscas nas bases de dados: Web of Science, National Library of Medicine, Cumulative Index to Nursing and Allied Health Literature. Resultados: identificaram-se 82.779 artigos, dos quais 13 foram analisados na íntegra. Jogos sérios apresentam menor custo comparados às simulações de procedimentos cirúrgicos, fácil acessibilidade e adequação ao desenvolvimento de habilidades cirúrgicas, treino de pacientes, aptidões, raciocínio clínico e tomada de decisão. Conclusão: os jogos sérios têm sido desenvolvidos por meio da elaboração de softwares e ferramenta de interatividade específica, principalmente os direcionados ao desenvolvimento de habilidades; com uso de componentes via internet, especialmente, na Medicina e Enfermagem; e utilizam periféricos dos próprios computadores nas estratégias de ensino-aprendizagem para incentivar o raciocínio clínico e a tomada de decisão.

Descritores: Jogos de Vídeo; Treinamento por Simulação; Educação em Saúde; Validação de Programas de Computador.

\footnotetext{
${ }^{1}$ Escola de Enfermagem de Ribeirão Preto, Universidade de São Paulo. Ribeirão Preto, SP, Brazil.

${ }^{2}$ Centro Universitário de Belo Horizonte. Belo Horizonte, MG, Brazil. 


\section{Introduction}

Through the evolution of society, at all times, advances have interfered and determined the need to implement sociocultural changes. Society admits that it is natural to face new situations that imply changes. In the educational scenario, however, the use of innovative concepts and techniques becomes essential to reconcile and harmonize the teaching-learning process with the state of cultural and technological development new generations of students present.

Thus, it is a function of education to be always attentive to the expectations and profile of the students, in order to innovate and adopt techniques and methods capable of promoting a healthy teaching-learning process that favors the satisfaction of all stakeholders $^{(1)}$.

In this perspective, studies that aim to promote innovation in the scenarios of teaching practice are of relevance because it is essential to attend to the needs of the clientele and to prepare the teachers for the adoption of changes. Thus, this study aims to contribute in this sense, also considering that serious games have been used as an effective tool for competency building among health professionals.

It is of common agreement that the field of Information and Communication Technologies has enabled the development and growth of several areas of science, including the health sciences. In professional education, the changes in teaching / learning paradigms currently place the student at the center of learning, considerably increasing the need for innovative strategies, among which the use of simulation can be highlighted ${ }^{(2)}$.

In Health and Nursing, the use of simulated teaching provides active learning, which reinforces the theoretical knowledge acquired in the classroom and contributes to the student's own participation in learning. They harmonize the reflection of the new content based on the student's background knowledge, which generates significant learning ${ }^{(3)}$. In the use of simulation, strategies promote students' co-accounta- bility in their learning process and the development of ethical attributes linked to patient safety ${ }^{(4)}$.

Among the various resources used for this teaching-learning method, the use of simulated games in a virtual reality environment, also known as serious games $^{(5)}$, has increased. These have a number of meanings and can be described as virtual games simulated for educational purposes and not just entertainment. They have been considered as important and innovative tools for training human resources in health, with emphasis on the education of nursing professionals, both in skills training, in the formation of critical sense, decision making and reasoning; the serious games develop competences related to the provision of materials and equipment and to the stages of the procedures, permitting the repetition of the training and, in some cases, favoring the critical judgment to support the manual dexterity ${ }^{(5)}$.

Virtual games were introduced by the industry as a mere instrument of children's entertainment, but today their applicability has been exploited in a professional way, in several areas of knowledge and based on scientific evidence, which motivated the need to formulate methods and guidelines and the concern about what would be defined as serious games ${ }^{(6)}$.

Serious games are learning objects mainly characterized by the concern to transmit knowledge through digital media. These are tools that have the potential to change educational paradigms and that stand out in many aspects when compared to traditional teaching-learning methods ${ }^{(7)}$.

Some of the benefits of virtual games applied to health are: safety for the student and the patient, reducing and preferably avoiding the possibility of error and control of events, motivating and facilitating effect on learning; development of cognitive skills, discovery learning, experience of new identities, socialization, motor coordination and expert behavior. It is considered difficult, however, to play a game to exploit all these benefits, because some drawbacks still remain, such as the lack of this kind of products in the market, the slow adaptation of educators in the 
use of this tool and the imprecision of what gaming companies are producing, which remain much more concerned with the market for the game than with the pedagogical gains ${ }^{(8)}$.

The technological resources used in this tool employ current, promising technologies that grow exponentially, change and improve constantly, but not always with evidence of success. In order to be applied, they need to be evaluated in their area of knowledge, in order to choose the best evidence.

In this sense, the objective was to identify in the literature how the use of serious games in virtual environments has evolved for teaching and learning in health.

\section{Methods}

An integrative review of the literature was undertaken. The methodological development was subdivided into six phases: elaboration of the guiding question; establishment of inclusion and exclusion criteria and literature search; definition of the information to be extracted from the selected studies; evaluation of included studies; interpretation of results and presentation of the review ${ }^{(9)}$.

The guiding question elaborated for selecting the articles was: how has the use of serious games evolved in virtual environments for teaching and learning in health? For the search, the following databases were used: Web of Science, National Library of Medicine (PubMed), Cumulative Index to Nursing and Allied Health Literature (CINAHL).

To accomplish the search, the descriptors were defined as: video games, games, video, simulation training, simulation, health education, software validation. Publications were included that were published in the period 2010 to 2016 in English, Portuguese and Spanish, available in full, which discussed the research question in the teaching of health professionals, based on a qualitative and/or quantitative method, which contributed to understand the study phenomenon.

Of the 82,779 publications found, 168 were selected and, after exhaustive reading of the titles and abstracts, 72 full studies were selected for reading, while 59 were excluded because they did not answer the research question. Thus, 13 articles met the established inclusion criteria, being selected for analysis. The 13 articles were later analyzed using a bibliographical data collection tool ${ }^{(10)}$, which included data related to the identification of authorship, year of publication, journal, methodological design, the intervention studied, the main results and the conclusions.

The analysis of the ranking of the evidence in the article was based on a proposed six-level ranking, namely: Level I, studies related to the meta-analysis of multiple controlled studies; Level II, individual experimental studies; Level III, quasi-experimental studies, such as non-randomized clinical trial, single pre- and post-test group, and time series or case-control; Level IV, non-experimental studies, such as descriptive, correlational and comparative research, with a qualitative approach and case studies; Level V, evaluation data of programs obtained systematically and Level VI, expert opinions, experience reports, consensuses, regulations and legislation ${ }^{(11)}$.

The methodological details were based on the literature and the results were presented descriptive$\mathrm{ly}^{(12)}$. The articles analyzed were identified from one to 13 , adopting the term technology, defined as a force of cultural transformation $^{(13)}$.

\section{Results}

Among the 13 articles included in the study, 12 were published in English and one in Portuguese. The knowledge areas of the studies were Medicine (nine) and Nursing (four). The research data related to authorship, year of publication, country, knowledge area and evidence level are displayed in Figure 1.

Therefore, the sample consisted of 13 articles, developed in eight countries and published in 13 journals.

The main results and conclusions of the publications analyzed are displayed in Figure 2. 


\begin{tabular}{|c|c|c|c|c|c|}
\hline ID & Author & Year & Country & Area & Evidence level \\
\hline 1 & Dariel et al. ${ }^{(14)}$ & 2013 & France & Nursing & $\mathrm{VI}$ \\
\hline 2 & Wit-Zuurendonk \& Oei $i^{(15)}$ & 2011 & The Netherlands & Medicine & IV \\
\hline 3 & Diehl et al. ${ }^{(16)}$ & 2013 & Brazil & Medicine & II \\
\hline 4 & Fonseca et al. ${ }^{(17)}$ & 2014 & Brazil & Nursing & IV \\
\hline 5 & Munro $^{(18)}$ & 2012 & USA & Medicine & IV \\
\hline 6 & Consorti et al..$^{(19)}$ & 2012 & Italy & Medicine & $\mathrm{I}$ \\
\hline 7 & Solomon et al. ${ }^{(20)}$ & 2011 & USA & Medicine & VI \\
\hline 8 & Jalink et al. ${ }^{(21)}$ & 2013 & USA & Medicine & III \\
\hline 9 & Ruthenbeck et al $^{(22)}$ & 2012 & Australia & Medicine & IV \\
\hline 10 & Clarke et al. ${ }^{(23)}$ & 2012 & Canada & Medicine & IV \\
\hline 11 & Farra et al. ${ }^{(24)}$ & 2015 & USA & Nursing & $\mathrm{V}$ \\
\hline 12 & Corradi et al. ${ }^{(25)}$ & 2011 & Brazil & Nursing & IV \\
\hline 13 & Papatsoris et al. ${ }^{(26)}$ & 2012 & United Kingdom & Medicine & III \\
\hline
\end{tabular}

Figure 1 - Results found in the studies according to author, year of publication, country, knowledge area and evidence level

\section{ID Main results and conclusions of the studies analyzed}

1 The serious games are efficient teaching and learning tools that offer safety to the teachers and allow the student to develop skills and competencies, to apply clinical reasoning and recognize the consequence of this reasoning.

2 Serious games are being applied as an auxiliary tool in the teaching of medicine, to improve the technical and clinical decision-taking skills. They are low-cost and offer possibilities to simulate scenarios that are unfeasible in real life.

3 It was demonstrated that, in a multiprofessional team, a virtual learning object can be created with possibilities for attractive and low-cost applications to guarantee better care for diabetes patients.

4 A learning object was constructed, based on the teaching and learning theories, at a low cost and with a low access level to improve the care for vulnerable populations.

The current simulators offer the opportunity to develop surgical skills, and the virtual-reality simulation models have not surpassed

5 them yet. Validation studies are now needed, as well as cost assessments to purchase hardware and software. In the future, the role of simulation in virtual reality will gain broader dimensions.

6 It was evidenced that the virtual teaching method is superior when compared to the traditional model. Its inclusion in the curricula is recommended.

7 The reality of the virtual simulation of a cognitive task can overcome the deficiencies of the existing education models.

8 The fictional construction of a valid prototype virtual game with considerable perspectives was demonstrated for the training of laparoscopy skills.

9 The final assessment was positive, indicating that the simulator can support surgeons to gain amygdalectomy skills rapidly in a safe and realistic environment.

10 The surgical essay of complex procedures in virtual reality simulation can be performed for specific patients according to advances in the simulation technologies (preview).

11 Virtual reality is an important strategy for health professional training and permits the inclusion of evidence into clinical practice.

12 The use of computer technologies integrated in undergraduate Nursing teaching should support the teaching and learning process of 12 the physical examination, optimizing the results inside and beyond the classroom.

13 Virtual-reality simulated training can reduce risks in the initial phase of the learning curve of percutaneous renal access, improving 13 several skills required for this technique.

Figure 2 - Synthesis of results and conclusions of the selected articles 
In Figure 3, the distribution of the primary studies is displayed according to the technologies used, the interactivity tools and the target audience.

\begin{tabular}{|l|c|c|c|}
\hline ID & $\begin{array}{c}\text { Technolo- } \\
\text { gies used }\end{array}$ & Interactivity tools & Target audience \\
\hline 3 & Web-based & Mouse & Medical professionals \\
\hline 4 & Web & Mouse & Nursing graduates \\
\hline 7 & Software & $\begin{array}{c}\text { Haptic } \\
\text { Virtual reality }\end{array}$ & $\begin{array}{c}\text { Medical graduates and } \\
\text { professionals }\end{array}$ \\
\hline 8 & Software & $\begin{array}{c}\text { Haptic } \\
\text { Laparoscopy simulator }\end{array}$ & $\begin{array}{c}\text { Medical graduates and } \\
\text { professionals }\end{array}$ \\
\hline 9 & Software & $\begin{array}{c}\text { Haptic } \\
\text { Tonsillectomy simulator }\end{array}$ & Surgeons \\
\hline 10 & Software & Haptic & Surgeons \\
\hline 12 & Web & Mobile technology (mobile) & Nursing graduates \\
\hline 13 & Software & Hroptic & Medical professionals \\
\hline
\end{tabular}

Figure 3 - Articles according to technologies used, interactivity tools and target audience

\section{Discussion}

It should first be pointed out that, as a first approach to the subject in the form of a literature review, one of the limitations of this study is the number of databases used. The main bases for the theme studied were adopted as selection criteria, but variations may occur if other bases are included. Considering that this is a new and expanding topic, the standardization of the terms in the databases may not be well structured yet, which may hinder the retrieval of articles.

In this study, it was observed that, during the last five years included in this review, there was an increase in the dissemination of research on the theme, mainly between 2011 and 2013. The greatest emphasis was found on clinical studies (Nursing and Medicine) and the highest prevalence of publications was in the developed countries of the Northern hemisphere.

Among the studies produced, as shown in Figure 1, several levels of evidence were identified, although with a predominance of non-experimental and case studies, which indicates that the levels of research on the subject are in the reporting phase of the elaboration of the games and that, possibly, soon, the journals will publish the evaluation of the produced items ${ }^{(27)}$.

Among the research analyzed, also shown in Figure 1 , it is observed that the articles proposed were focused on the description of pedagogical models and the evidences of the literature on the subject; the development of clinical reasoning and the improvement of motor skills. Simulation technology in virtual reality has been massively applied in health education, especially in the form of serious games, associated with complex hardware or just simple computers. Several areas of knowledge have established this method as a support tool in didactic activities, highlighting the development of motor skills. Serious games are embedded in active methods ${ }^{(28)}$.

Stimulated by the possibility of manufacturing and the availability of easy access to the equipment, serious games made it possible for students from diverse knowledge areas, thrilled by the innovative and pioneer spirit, to develop prototypes, learning objects, focused on specificities, with good interactivity and low cost. Specifically in the area of health, the convenience and effectiveness of serious games generate questions, resulting from the lack of reliable data on validity, as well as from the lack of methodological information about the production. The construction of serious games for use in the health area requires mastery of the thematic content, as well as mastery of other areas of technological knowledge, such as information technology and design; without this partnership in the innovation process, there is a risk of launching products that do not meet the strategies of using the virtual learning object as an ally of the teaching-learning process ${ }^{(5,28)}$.

With regard to the production of serious games, the technologies currently available permit countless forms of interaction between men and machines by means of mouse, different sensors, voice commands, eye movements and other forms created by enthusiasts and innovators. In the studies analyzed, concerns could be observed with the development of more sensitive sensors and the reinforcement of motor skills, especially in games created for the medical 
area. For the development of motor skills, in most of the studies, the haptic concept was used, aiming to guarantee immediate tactile feedback during the simulation, which allows the simulation to become even more realistic and guarantee the possibility of evaluating both the tutor and the apprentices ${ }^{(29)}$.

Kinect, a sensor from Microsoft, figured as a breakthrough in the gaming market by offering new interaction between the player and the digital media by capturing body movement. In addition, the tool has great potential in health-related projects, and can be associated with applications the users developed themselves ${ }^{(30)}$, offering an optimistic perspective in the current simulation area with a relevant role for serious health games ${ }^{(27)}$.

Simulation in a virtual environment does not pretend to replace the traditional forms of teaching used in health, but presents itself as an auxiliary tool, with proposals and possibilities that depend on the creativity and commitment of users. Applied in the form of serious games, they provide learning objects that can guarantee motivating and enriching interaction both in the cognitive and motor part for the generation of college students for whom these technologies are much more attractive and motivating to learn. In surgical disciplines, virtual reality simulation is associated with hardware in order to ensure a realistic tactile sensation; on the other hand, nursing uses the strategy for clinical reasoning and agile decision taking. Investing in this process is vital for the sake of researchers, teachers and students' adherence in the innovation process in health teaching.

\section{Conclusion}

Serious games have been developed through the elaboration of software and specific interactivity tools, mainly focused on skills development; involving the use of Internet components, particularly in Medicine and Nursing; and use computer peripherals in the teaching and learning strategies to encourage clinical reasoning and decision taking.

\section{Acknowledgements}

This research is part of a Communication, Science and Technology Project developed by researchers from the Study and Research Group on Communication in the Nursing Process, funded by the National Council for Scientific and Technological Development (CNPQ/Brazil), Institutional Scientific Initiation Scholarship Program (PIBIC) 0214-355 and Universal Call 477954/2012-0.

\section{Collaborations}

Santos CA, Souza-Junior VD and Jorge BM contributed to the conception and project, analysis and interpretation of the data, writing of the article and final approval of the version for publication. Lanza FF and Lacerda AJ contributed to the conception and project and final approval of the version for publication. Mendes IAC contributed to the conception and project, writing of the article, relevant critical review of the intellectual content and final approval of the version for publication.

\section{References}

1. Trevizan MA, Mendes IACosta, Mazzo A, Ventura CAA. Investment in nursing human assets: education and minds of the future. Rev Latino-Am Enfermagem. 2010; 18(3):467-71. doi: http:// dx.doi.org/10.1590/S0104-11692010000300024

2. Miller A, Bull RM. Do you want to play? Factors influencing nurse academics' adoption of simulation in their teaching practices. Nurse Educ Today. 2013; 33(3):241-6. doi: http://dx.doi. org/10.1016/j.nedt.2011.11.001

3. Sousa ATO, Formiga NS, Oliveira SHS, Costa MML, Soares MJGO. Using the theory of meaningful learning in nursing education. Rev Bras Enferm. 2015; 68(4):626-35. doi: http://dx.doi. org/10.1590/0034-7167.2015680420i 
4. Foronda CL, Alfes CM, Dev P, Kleinheksel AJ, Nelson DA Jr, O’Donnell JM, et al. Virtually nursing: emerging technologies in nursing education. Nurse Educ. 2017; 42(1):14-7. http://dx.doi. org/10.1097/NNE.0000000000000295

5. Saunder L, Berridge, EJ. Immersive simulated reality scenarios for enhancing students' experience of people with learning disabilities across all fields of nurse education. Nurse Educ Pract. 2015; 15(6):397-402. doi: http://dx.doi. org/10.1016/j.nepr.2015.04.007

6. Dithmer M, Rasmussen J0, Grönvall E, Spindler H, Hansen J, Nielsen G, et al. "The heart game": using gamification as part of a telerehabilitation program for heart patients. Games Health J. 2016; 5(1):27-33. doi: http://dx.doi.org/10.1089/ g4h.2015.0001

7. Lewis ZH, Swartz MC, Lyons EJ. What's the Point?: a review of reward systems implemented in gamification interventions. Games Health J. 2016; 5(2):93-9. doi: http://dx.doi.org/10.1089/ g4h.2015.0078

8. Savi R, Ulbricht VR. Jogos digitais educacionais: benefícios e desafios. Rev Novas Tecnol Educ [Internet]. 2008 [citado 2017 set 10]; 6(2):1-10. Disponível em: http://seer.ufrgs.br/index.php/ renote/article/view/14405/8310

9. Mendes KDSM, Silveira RCCP, Galvão CM. Revisão integrativa: método de pesquisa para a incorporação de evidências na saúde e na enfermagem. Texto Contexto Enferm. 2008; 7(4):758-64. doi: http://dx.doi.org/10.1590/ S0104-07072008000400018

10. Ursi ES, Galvão CM. Prevenção de lesões de pele no perioperatório: revisão integrativa da literatura. Rev Latino-Am Enfermagem. 2006; 14(1):12431. doi: http://dx.doi.org/10.1590/S010411692006000100017

11. Stetler CB, Morsi D, Rucki S, Broughton S, Corrigan $B$, Fitzgerald J, et al. Utilization-focused interative reviews in a nursing service. Appl Nurs Res. 1998; 11(4):195-206. doi: http://dx.doi.org/10.1016/ S0897-1897(98)80329-7

12. Polit DF, Beck C. Nursing research: Generating and assessing evidence for nursing practice. Philadelphia: Lippincott, Williams \& Wilkins; 2012.
13. Petit dit Dariel OJ, Raby T, Ravaut F, RothanTondeur M. Developing the Serious Games potential in nursing education. Nurse Educ Today. 2013; 33(12):1569-75. doi: http://dx.doi. org/10.1016/j.nedt.2012.12.014

14. Wit-Zuurendonk LD, Oei SG. Serious gaming in women's health care. BJOG. 2011; 118(Suppl 3):17-21. doi: http://dx.doi.org/10.1111/j.14710528.2011.03176.x

15. Diehl LA, Souza RM, Alves JB, Gordan PA, Esteves $\mathrm{RZ}$, Jorge $\mathrm{ML}$, et al. InsuOnline, a serious game to teach insulin therapy to primary care physicians: design of the game and a randomized controlled trial for educational validation. JMIR Res Protoc. 2013; 2(1):e5. doi: http://dx.doi.org/10.2196/ resprot. 2431

16. Fonseca LMM, Dias DMV, Góes FSN, Seixas CA, Scochi CGS, Martins JCA. Development of the e-baby serious game with regard to the evaluation of oxygenation in preterm babies. Comput Inform Nurs. 2014; 32(9):428-36. doi: http://dx.doi. org/10.1097/CIN.0000000000000078

17. Munro MG. The surgical "Robot" in benign gynecology: surgical advance or a set of costly training wheels? J Minim Invasive Gynecol. 2016; 23(1):1-4. doi: http://dx.doi.org/10.1016/j. jmig.2015.10.016

18. Consorti F, Mancuso R, Nocioni M, Piccolo A. Efficacy of virtual patients in medical education: a meta-analysis of randomized studies. Comput Educ. 2012; 59(3):1001-8. doi: http://dx.doi. org/10.1016/j.compedu.2012.04.017

19. Solomon B, Bizekis C, Dellis SL, Donington JS, Oliker A, Balsam LB, et al. Simulating videoassisted thoracoscopic lobectomy: a virtual reality cognitive task simulation. J Thorac Cardiovasc Surg. 2011; 141(1):249-55. doi: http://dx.doi. org/10.1016/j.jtcvs.2010.09.014

20. Jalink MB, Goris J, Heineman E, Pierie JP, Ten Cate Hoedemaker HO. Face validity of a Wii U video game for training basic laparoscopic skills. Am J Surg. 2015; 209(6):1102-6. doi: http://dx.doi. org/10.1016/j.amjsurg.2014.09.034

21. Ruthenbeck GS, Tan SB, Carney AS, Hobson JC, Reynolds KJ. A virtual-reality subtotal tonsillectomy Simulator. J Laryngol Otol. 2012; 126(2):8-12.doi:http://dx.doi.org/10.1017/ S0022215112000199 
22. Clarke DB, D’Arcy RC, Delorme S, Laroche D, Godin G, Hajra SG, et al. Virtual reality simulator: demonstrated use in neurosurgical oncology. Surg Innov. 2013; 20(2):190-7. doi: http://dx.doi. org/10.1177/1553350612451354

23. Farra SL, Miller ET, Hodgson E. Virtual reality disaster training: translation to practice. Nurse Educ Pract. 2015; 15(1):53-7. doi: http://dx.doi. org/10.1016/j.nepr.2013.08.017

24. Corradi MI, Silva SH; Scalabrin EE. Virtual objects to support the teaching-learning process of physical examination in nursing. Acta Paul Enferm. 2011; 24(3):348-53. doi: http://dx.doi. org/10.1590/S0103-21002011000300007

25. Papatsoris AG, Shaikh T, Patel D, Bourdoumis A, Bach C, Buchholz N, et al. Use of a virtual reality simulator to improve percutaneous renal access skills: a prospective study in urology trainees. Urol Int. 2012; (89):185-90. doi: http://dx.doi. org/10.1159/000337530

26. Booth RG, Sinclair B, Brennan L, Strudwick G. Developing and implementing a simulated electronic medication administration record for undergraduate nursing education: using sociotechnical systems theory to inform practice and curricula. Comput Inform Nurs. 2017; 35(3):131-9. doi: http://dx.doi.org/10.1097/ CIN.0000000000000309
27. Oliveira SN, Prado ML, Silvana SK. Use of simulations in nursing education: an integrative review. Rev Min Enferm. 2014; 18(2):496504. doi: http://dx.doi.org/10.5935/14152762.20140036

28. Graafland M, Dankbaar M, Mert A, Lagro J, WitZuurendonk L, Schuit S, et al. How to systematically assess serious games applied to health care. JMIR Serious Games. 2014; 2(2):e11. doi: http://dx.doi. org/10.2196/games.3825

29. Ricciardi F, Paolis LTD. A comprehensive review of serious games in health professions. Int J Comput Games Technol. 2014; 2014:1-11. doi: http:// dx.doi.org/10.1155/2014/787968

30. Theng YL, Lee JWY, Patinadan PV, Foo Schubert SB. The use of videogames, gamification, and virtual environments in the self-management of diabetes: a systematic review of evidence. Games Health J. 2015; 4(5):352-61. doi: http://dx.doi. org/10.1089/g4h.2014.0114 